\title{
Ten false ideas about New Caledonia biogeography
}

\section{Philippe Grandcolas}

Institut de Systématique, Evolution, Biodiversité, ISYEB - UMR 7205 CNRS MNHN UPMC

EPHE, Muséum national d'Histoire naturelle,Sorbonne Universités, CP 50, 45 rue Buffon, 75005, Paris, France

\begin{abstract}
The biogeographical paradigm of New Caledonia has recently changed. Although this island is now considered by many asoceanic, its study is still often impeded by some old misconceptions concerning either regional geology or phylogenetic analysisof evolution and biogeography. I discuss ten points that I feel are especially detrimental, to help focus on the real debate andthe real questions: (1) its geological history cannot be understood from the basement only; (2) the island submergence was notdue simply to sea-level variation; (3) Zealandia/Tasmantis is not a lost continent; (4) short-distance dispersal is not equivalent topermanence on land; (5) longdistance dispersal is not the sole event opposing vicariance, but short-distance dispersal as well; (6) the occurrence of relicts does not prove biota permanence; (7) a major fault system was not observed in New Caledonia; (8) terranes are not rafts; (9) forest climatic refuges do not necessarily equate to centres of endemism or centres of diversity; and (10)New Caledonia is not only a sink but also a source. Study of New Caledonia will need to focus on old and non-relict clades and there is a need to improve the local fossil record.
\end{abstract}

Islands have always fascinated biogeographers andtheir study has seen the emergence of several paradigms (Darwin, 1859; Wallace, 1881; Darlington, 1957; MacArthur and Wilson, 1967; Nelson and Platnick,1981). These authors traditionally distinguished oceanic islands that were never connected to continents and emerged in the middle of oceans, as opposed to continental islands. The biotas of oceanic islands werenecessarily formed entirely by dispersal. In this context, opinions regarding New Caledonia have varied considerably. In early studies, New Caledonia was considered as an island intermediate between continental and oceanic and its biota was assumed to haveresulted from both vicariance and dispersal (Darwin,1859; Wallace, 1881; Jeannel, 1942; Faivre et al., 1955;Darlington, 1957; Wilson, 1961). In the second half of the twentieth century, some scientists came back to the idea of a continental island by presenting New Caledonia as a stunning Gondwanan refuge, based on its continental geological basement and the presence oflocal relict taxa (Raven and Axelrod, 1972; Holloway,1979; Stevens, 1980; Lowry, 1998). This view prevailed for several decades until recent studies showed both its discordance with geology and the pitfalls of using relicts in biogeography (Murienne et al., 2005; Grandcolas et al., 2008, 2014; Murienne, 2009; Swensonet al., 2014). In this way, several reviews showed thatmolecular phylogenies dated New Caledonian clades(Grandcolas et al., 2008; Cruaud et al., 2012; Pillon,2012) to after the reemergence of the island, i.e. prob-ably 373 Ma according to geology (Paris, 1981; Aitchison et al., 1995; Cluzel et al., 2001; Cluzel et al.2012; Crawford et al., 2003; Pelletier, 2007). Science is, however, not consensus and several papers have recently 
objected to the apparent congruence between systematics and geology by arguing for permanence of New Caledonian biota withad hoc scenarios of short-distance dispersal (SDD) among nearby islands (Ladiges and Cantrill, 2007; Heads, 2008a, 2010). All these studies showed that New Caledonia is an interesting place for biogeography, and should allow us to disentangle the respective roles of vicariance anddispersal and open a very wide time window to test varied evolutionary scenarios. Some geological or biological inferences or theories already well established should be carefully specified for the debate could focus on the real controversial questions. Here, I review tenpoints that are frequently misunderstood and that I feel important to clarify for enhancing the quality offuture research on New Caledonian biogeography.

Its geological history cannot be understood from the basement only

The deepest geological basement of New Caledonia has a very old continental origin (Paris, 1981; Pelletier,2007; Maurizot and Vendé-Leclerc, 2009; Cluzel et al.,2012). However, many different layers and rock types have been overlaid on this basement in the context ofsubsequent and complex tectonic events. It is therefore confusing to describe New Caledonia simply as a piece of Gondwana (Raven and Axelrod, 1972; Holloway,1979; Stevens, 1980; Lowry, 1998) and not to take into account the consequences of more recent geological events. First, as emphasized by Murienne et al. (2005)and Grandcolas et al. (2008), a recent and important submergence episode is documented by Palaeocene rock layers indicating deep marine sedimentation(thousands of metres) (Paris, 1981). This is the main evidence for submergence of the island: it does incorporate a few indirect assumptions, but merely strong stratigraphic and petrographic evidence interpreted inthe framework of the general regional tectonic model. Second, the ophiolitic nappe of Eocene lithospheric origin is also of particular significance. This geological structure has been known for a long time in relationto the discovery of nickel-rich soils and to the development of mining activities (Paris, 1981). Although it was considered as metamorphic or intrusive until the1970s (Avias, 1953; Routhier, 1953), the presence ofthe ophiolitic nappe had already made it clear that important environmental changes had occurred in the past in New Caledonia. Before the development of plate tectonics theory, this nappe was supposed to have been overlaid gently on marine and then on terrestrial biota. It was then assumed that local groups adapted progressively to ophiolitic rocks and to the subsequent nickel-rich and unbalanced soils (Morat et al., 1986). Since the 1990s, tectonics has developed integrative views based on several sources of data, from traditional historical geology and analyses of metamorphism to the study of boreholes. It was thus inferred that the ophiolitic nappe was overlaid byobduction of marine lithosphere (sea bottom) onto the island basement during a strong tectonic event, along with deep submergence of New Caledonia (Paris, 1981; Aitchison et al., 1995; Cluzel et al., 2001; Cluzel et al.2012; Crawford et al., 2003; Pelletier, 2007). Geologi-cally, New Caledonia is actually a piece of Gondwana, but it has existed as a terrestrial island only since $37 \mathrm{Ma}$ and it does not support any strong biogeographical hypothesis of a Gondwanan refuge. Speculating on the intensity and on the extent of the effectof the Eocene obduction 
on the New Caledonian landscape (Ladiges and Cantrill, 2007), that is complex to understand in details (Crawford et al. 2003; Pelletier,2007; Cluzel et al., 2012) will not save the Gondwanan refuge hypothesis, given the previous submergence episode that occurred already long after the separation from the remainder of Gondwana.

\section{Submergence was not like sea-level variation}

The paradigm of island submergence is sometimesseen as a minor geographical event that can be con-ceived by the mind of man, just like strong sea-level variation. In that line, some have assumed that Eocene mountain tops or parts of the island could have escaped submergence (Morat et al., 1984), as noticed by Murienne (2009). Although the mountain chains ofNew Caledonia are quite ancient (in contrast to those of New Zealand), the magnitude of the long tectonic events during the Palaeocene and Eocene was inferred to be so important that a large part of the basement was deep beneath the sea surface and partly beneath bottom-sea lithosphere. New Caledonia is a long and narrow island whose longest dimension is parallel to the borders of the tectonic plates. It was then strongly submitted to tectonic events. The island is remarkably well studied from a geological point of view and it is clear that it was deeply submerged during major tec-tonic events, the intensity of which needs to be properly understood by biologists (Paris, 1981; Aitchisonet al., 1995; Cluzel et al., 2001; Cluzel et al. 2012;Crawford et al., 2003; Pelletier, 2007).

\section{Zealandia/Tasmantis: not a lost continent}

The name 'Zealandia' is increasingly used in the literature to characterize a large area of diverse continen-tal rocks that notably includes the basement of New Zealand and New Caledonia (Luyendyk, 1995; Mor-timer, 2004; Trewick et al., 2007). The continental nat-ure of these rocks was known since long ago (Paris,1981), and until recently the area was known underthe name 'Tasmantis' employed both as regards geology (Avias, 1955; Lillie and Brothers, 1970) and biogeography (Smith et al., 2007). However, naming such a geological diverse entity may be confusing for some biogeographers and lead them to assume that it could have behaved as a lost continent (i.e. a large terrestrial land mass some parts of which were flooded while others remained emerged), determining to shared distributions between terrestrial groups (e.g. Wanntorp et al., 2011). The lost continent paradigm can betraced back to the biblical story of the Deluge, employed in the earliest evolutionary scenarios fromthe Middle Ages to explain the occurrence of fossils: a large area of terrestrial land is supposed to be almost entirely flooded, determining a strong pattern of rela-tionships between the remaining emerged parts. This scenario implies naive assumptions predating tectonics: the area is supposed to be affected as a whole by a process combining relative terrestrial land stability and sea-level variation, implying flooding after a rise in thesea level or the collapse of the continent. In contradic-tion, tectonics showed from the mid-twentieth century that the landscape can be shaped by very strong events in a much more 
complex manner, including not only sea-level variation but also land subduction, uplift, orogenesis and subsidence occurring very locally and possibly in close opposition. The lost continent story recalls the long-standing myth of 'Pacifica' (Gregory,1930), briefly resurrected by some biogeographers (Melville, 1966; Nur and Benavraham, 1977; Nelsonand Platnick, 1981). Pacifica has been discounted (Nunn, 2009) but unfortunately Zealandia/Tasmantis remains fascinating, because New Zealand and NewCaledonia are traditionally considered as continental by many. Zealandia or Tasmantis is not a name for a past terrestrial geographical unit but for a complex series of rock layers that implies diverse emergent andsubmergent lands at different periods and after different events of subduction, uplift or sea-level variation,and ending today with a large ocean surface where more or less ephemeral islands are scattered.

\section{SDD is not equivalent to local permanence}

In the same line of reasoning, assumptions of SDD are often used to rescue vicariance scenarios. Following the confrontation between modern regional studies ofbiogeography and geology (Murienne et al., 2005; Grandcolas et al., 2008), some authors realized thatstrict in situ permanence of biota has become an untenable hypothesis for New Caledonia. They then argued that hopping among ephemeral islands on the Norfolk Ridge could explain the permanence of old groups in New Caledonia (Ladiges and Cantrill, 2007; Heads,2008a). This scenario was envisaged by many studies asone among many possible others (Morat et al., 1986; Swenson et al., 2001; Grandcolas et al., 2008) and it has been made testable by investigating whether the oldest inclusive insular Pacific clade is older than the oldest island, i.e. New Caledonia (Nattier et al., 2011; Swenson et al., 2014). The congruence of this scenario with geology remains to be studied; vanished islandscertainly existed but were not suspected to be at theright place or the right time by geologists (Murienneet al., 2005; Grandcolas et al., 2008; Murienne, 2009).Regardless, it should be made clear that SDD is not equivalent to local permanence and cannot be taken as an argument to preserve the assumption of an anterior vicariance event between New Caledonia and adjacentso-called Gondwanan territories. Series of combined SDD events are mostly ad hoc hypotheses, the accumulation of which constitutes 'a house of cards' (Crispet al., 2011). They typically represent a heritage of the literature of the early ages of biogeography (Wallace,1881; Zimmerman, 1942; Gressitt, 1956; Carlquist,1965; Axelrod, 1972), and now need to be placed in a testable framework.

\section{Dispersal (as opposed to vicariance) is either long orshort distance}

There are not two sorts of dispersal, the "bad" one (LDD), speculative and incompatible with biogeo-graphic hypotheses, and the "good" one (SDD), that can be assumed without too many risks. All assumptions of dispersal need to be treated as such and to besubmitted to attempts of refutation. In this respect, Ladiges and Cantrill (2007) or Heads (2008a) misrepresented the situation as if LDD was 
opposed to SDD and vicariance for explaining the origin of the New Caledonian biota. In fact, the antagonist assumptionsareany kind of dispersal (SDD or LDD) against vicariance and extinction. We have emphasized that assuming vicariance between New Caledonia and, say, Australia implied assuming a permanence of terrestrial biota in New Caledonia (Grand colas et al., 2008). To employ the specific terminology of Heads (2012), SDD was transmogrified into biotic permanence. Ad hoc dispersal assumptions have been extirpated from historical biogeography (Nelson and Platnick, 1981) and they should not now be reintroduced. Instead, it is better to refer to sister-group relationships, rather than misleadingly to permanence, SDD and vicariance.

\section{Relicts do not prove the permanence of biota}

Relicts are often taken as a conundrum (how dothey still exist?) or even as a strong indication that biota remain permanent (e.g. Ladiges and Cantrill, 2007; Heads, 2008a). They are also often mistaken for odd concepts such as a living ancestor, primitive taxon or missing link (O'Hara, 1992; Crisp and Cook, 2005; Crisp et al., 2011). The reasoning given at length inseveral recent reviews needs not be repeated here in detail: it clearly states that relicts remain from old groups depleted by extinctions and are not necessarily old species; they need to be studied in a documented phylogenetic framework with the possible help of the fossil record (Grandcolas et al., 2014; Grandcolas and Trewick, 2016). The presence of Amborella trichopoda in New Caledonia, a unique species considered by many as the sistergroup of all other flowering plants (Qiu et al., 1999), is one of the most emblematical examples of New Caledonian relicts. Unfortunately, although very impressive, this case remains inconclusive, as discussed in detail by Grandcolas et al. (2014): there is no informative fossil record for the monotypic genus Amborella that could allow us to disentangle the history of the very old stem-group from the history of the genus. Amborella trichopoda cannot be precisely dated; it may be very young as suggested by its recent local genetic differentiation (Poncet et al., 2013) or much older as allowed by its very deep stem-group. Recently, another case study of supposed relict, the group of Beauprea plants (Proteaceae), confused thedating of the crown-group and of the stem-group and misleadingly argued for permanence of the lineage in New Caledonia (He et al., 2016). Actually, relicts do not allow us to draw conclusions regarding phenotypic or geographical permanence; rather, they allow detecting large extinction events. In addition, assumptions of relicts and refuges are often twisted in a circular reasoning of mutual justification that needs to be broken (Waters and Craw, 2006).

Who has seen the fault?

It is difficult to refute the occurrence of something that has not been clearly observed nor explicitly described in detail. The case of supposed New Caledonia major fault given by Heads (2008b) is strange. Heads (2008b) referred to geological studies that didnot explicitly mention the fault or did not figure it. Most of the studies cited by 
Heads (2008b) are outdated regional syntheses and mentioned the fault under different concepts or names (sillon, furrow, line of weakness, fracture zone, geosuture, etc.), and often just in passing. Heads (2008b) himself recognized that local and recent field studies did not recognize it as a major feature along the entirety of New Caledonia (Cluzel et al., 2001; Chardon and Chevillotte, 2006).The geological maps of Paris (1981), the recently published Atlas of New Caledonia (Bonvallot et al., 2012) and the recent geological map of New Caledonia available online (Maurizot and Vendé-Leclerc, 2009) did not show any major fault. The assumed distributional disjunctions (Heads, 2008b) along the unobserved fault represent small-scale distributional patterns that are often poorly documented and that can be interpreted within the framework of phylogenetic studies alongwith recent environmental change (Murienne, 2009;Nattier et al., 2012, 2013; Anso et al., 2016).

\section{Terranes are not rafts}

Another popular word in some recent biogeographi-cal studies is "terrane". And as with "Zealandia" and"dispersal”, it has gained particular significance, apparently much further than justified by the actual evidence. Undoubtedly, present-day New Caledonia is an accumulation of rocks of different origins onto a continental basement (Paris, 1981; Maurizot and Vendé-Leclerc, 2009). However, the reasoning that different lineages were brought by different terranes (Heads, 2008a, 2010) can be easily refuted (Murienne, 2010). From a biological point of view, tree topology or dating did not fit the theory of diverse origins by means of different terranes: the vast majority of local clades are more recent than $37 \mathrm{Ma}$ and the so-called terranes. From a geological point of view, the terranes were emplaced during tectonic events the reconstruction of which implies most often non-biotic terrestrial conditions (see for example the ophiolitic nappe discussed in section "Its geologicalhistory cannot be understood from the basement only"). How could living things travel with lithosphere obducted onto the basement in the Eocene sea bottom? This appears to be a revival of the old demons of bio-geography; after the emphasis placed on the role of SDD, now comes the role of rafts.

Forest climatic refuges $=$ centres of endemism $=$ centres of diversity $?$

Along with the idea of relicts and escape from submergence often comes the concept of climatic forest refuges (Pintaud et al., 2001; Poncet et al., 2013; Pouteau et al., 2015). The core idea conflating relicts and refuges is that some areas may be especially stable and hospitable and then shelter the remaining old lineages, an idea that is quite widespread in the literature (Parsons, 2005; Grandcolas et al., 2014; Jordan et al., 2015; Proches et al., 2015). In this view, New Caledonia would be a kind of multi-million-year arch based on the combination of assumptions of a Gondwanan refuge and climatic stability in an oceanic insular context (for a similar view on New Zealand, see Gibbs, 2006). The first part of the reasoning is flawed as the island was submerged repeatedly and the second part lacks continuity with the first part. 
Positing areas of suitable climatic during the changes of the latest Quaternary may be possible and could elegantly explain some present-day distributions (Pouteau et al., 2015). It does not mean, however, that such areas remain at the same place or of the same nature over millions of years, given that NewCaledonia moved from subtropical to tropical latitudesand that the regional climate has changed dramatically since the Eocene (Reusch, 2011). For example, Nattier et al. (2012) showed that the distribution area of microendemic species increased considerably with time, placing the oldest endemics in secondary sympatry. In this context, some Quaternary forest climatic refuges could be centres of endemism for some groups at the least, but they do not necessarily equate to centres of diversity or even centres of origin where a significant amount of deep time evolution is conserved (Pellens et al., 2016). As an example, the most emblematical relict in New Caledonia, Amborella trichopoda, considered by many as the sister-group of flowering plants, has a quite wide distribution on the island and is not restricted to particular areas of long-term stability (Poncet et al., 2013; Pouteau et al., 2015).

Islands: sinks or sources, or both?

Oceanic islands were often considered as sinks wherea few continental lineages established by dispersal (e.g. MacArthur and Wilson, 1967). Continental islands were seen as refuges where old lineages remained, as emphasized by Gillespie and Roderick (2002). Both paradigms do not fundamentally envisage that islands can be sources for continents or other islands, but more or less ancient sinks. New Caledonia has been considered according to both these classical paradigms and therefore, until recently, never as a source. However, this situation changed as dispersal from islands back to continents recently became an attractive idea (Bellemain and Ricklefs, 2008) and a recent and elegant analysis revealed that New Caledonia and New Zealand have been both sinks and sources in the case of coniferous plants (Condamine et al., 2016). The change of paradigm is not fundamentally innovative as the most basic difference between a source and a sink is a scale effect: being larger and older, an area is expected to shelter more lineages with lower rates of extinction, and whose significantly higher ratio will be able to colonize other areas and to act as a source. The model behind the sink and source paradigm could take into account many other parameters, such as geographical pathways (not just dispersal), climatic equitability/stability and empty niches, that can differ significantly for islands. For New Caledonia, such a paradigmatic change is especially important as it helps in considering the island as otherwise than a Gondwanan refuge/sink. It also echoes the previous consideration that New Caledonia is not a museum but rather a cradle of diversity given the local diversification rates in several groups (Espeland and Murienne, 2011).

Conclusions: what has to be done for New Caledonia?

Listing these ten misleading ideas allows us to draw some general lines of research for the future. First, old ad-hoc assumptions in biogeography such as SDD and rafts must be made carefully testable; such assumptions have appeared recurrently in the literature 
and some recent views have repeated with few changes what can be found in Wallace (1881) without giving the appropriate credit. Clearly, the problem is not that such assumptions are formulated (to the contrary) but rather that they have rarely been properly tested. Second, to perform decisive tests, we need to carefully consider a relevant and accurate taxonomic or geographical sample (e.g. Nattier et al., 2011; Swenson et al., 2014; Anso et al., 2016; Skipwith et al., 2016). Sampling accuracy often needs to be improved by long field and taxonomic studies (Najt and Matile, 1997; Najt and Grandcolas, 2002; Grandcolas, 2008, 2009; Guilbert et al., 2014). Third, geological knowledge needs to be confronted with biological analyses and not directly integrated within them to avoid circular reasoning (Waters and Craw, 2006). This geological knowledge must be evaluated carefully with respect to the magnitude or the environmental significance of past events. Ideally, future studies should explore the whole regional time frame of evolution from the breakup of Gond-wana (>80 Ma) to the emergence of New Caledonia (37 Ma). This means focusing on old clades, but not necessarily on relict ones that are so depleted that they do not provide a sample of correct taxonomic diversity in space and time, except in the rare case of an accurate fossil record (Grandcolas et al., 2014). The fossil record itself should not be considered as a backbone that is seldom available from the literature but rather should be actively improved upon to get direct information on the early distribution and characteristics of taxa. A rich local Quaternary record has already been studied inNew Caledonia (Balouet and Olson, 1989; Andersonet al., 2010; Worthy et al., 2016) and an older and probably even richer record is available from the Cretaceous-Miocene (Genise et al., 2012; R.

Garrouste,A. Nel, P. Grandcolas, unpubl. data). It is only under these conditions that New Caledonia will become a natural laboratory comparable to other island systems.

\section{References}

Aitchison, J.C., Clarke, L., Meffre, S., Cluzel, D., 1995. Eocene arc-continent collision in New Caledonia and implications for regional Southwest Pacific tectonic evolution. Geology 23, 161-164.

Anderson, A., Sand, C., Petchey, F., Worthy, T.H., 2010. Faunal extinction and human habitation in New Caledonia: initial results and implications of new research at the Pindai Caves. J.Pacif. Archaeol. 1, 89-109

Anso, J., Barrabé, L., Desutter-Grandcolas, L., Jourdan, H.,Grandcolas, P., Dong, J., Robillard, T., 2016. Old lineage on an old island: Pixibinthus, a new cricket genus endemic to New Caledonia shed light on gryllid diversification in a hotspot of biodiversity. PLoS One 11, e0150920.

Avias, J. 1953. Contribution à l'étude stratigraphique et paléontologique des formations anté crétacées de la Nouvelle-Calédonie centrale. Sciences de la Terre, Nancy.

Avias, J., 1955. A propos des "terres disparues" du Pacifique austral; tasmantis et Tasmantia. Compte Rendu Sommaire des Séances de la Société Géologique de France, 15-16, 332-334.

Axelrod, D.I. 1972. Ocean-floor spreading in relation toecosystematic problems. In: Allen, R.T., James, F.C. (Eds.),Symposium on Ecosystematics (1971): University of Arkansas. Occ. Paper, University of Arkansas Museum, Fayetteville, AR, pp. 15-68.

Balouet, J.C., Olson, S.L., 1989. Fossil birds from late Quaternary deposits in New Caledonia. Smiths. Contr. Zool. 469, 1-38.

Bellemain, E., Ricklefs, R.E., 2008. Are islands the end of thecolonization road? Trends Ecol. Evol. 23, 461-468. 
Bonvallot, J., Gay, J.C., Habert, E. 2012. Atlas de la Nouvelle-Calédonie. IRD - Congrès de la Nouvelle-Calédonie, Marseille-Nouméa.

Carlquist, S. 1965. Island Life. The Natural History Press, NewYork.

Chardon, D., Chevillotte, V., 2006. Morphotectonic evolution of theNew Caledonia ridge

(Pacific Southwest) from post-obduction tectono-sedimentary record.

Tectonophysics 420, 473-491.

Cluzel, D., Aitchison, J.C., Picard, C., 2001. Tectonic accretion andunderplating of mafic terranes in the Late Eocene intraoceanicfore-arc of New Caledonia (Southwest Pacific): geodynamicimplications. Tectonophysics 340, 23-59.

Cluzel, D., Maurizot, P., Collot, J., Sevin, B., 2012. An outline ofthe Geology of New Caledonia; from Permian-MesozoicSoutheast Gondwanaland active margin to Cenozoic obductionand supergene evolution. Episodes 35, 72-86.

Condamine, F.L., Leslie, A.B., Antonelli, A., 2016. Ancient islandsacted as refugia and pumps for conifer diversity. Cladistics. doi:10.1111/cla.12155.

Crawford, A.J., Meffre, S., Symonds, P.A., 2003. Chapter 25-120to 0 Ma tectonic evolution of the southwest Pacific andanalogous geological evolution of the 600 to $220 \mathrm{Ma}$ TasmanFold Belt system. Geol. Soc. Austral. Spec. Publ. 22, 377-397.

Crisp, M.D., Cook, L.G., 2005. Do early branching lineages signifyancestral traits? Trends Ecol. Evol. 20, 122-128.

Crisp, M.D., Trewick, S.A., Cook, L., 2011. Hypothesis testing inbiogeography. Trends Ecol. Evol. 26, 66-72.

Cruaud, A., Jabbour-Zahab, R., Genson, G.E., Ungricht, S.,Rasplus, J.Y., 2012. Testing the emergence of New Caledonia: figwasp mutualism as a case study and a review of evidence. PLoSOne 7, e30941.

Darwin, C.R., 1859. On the Origin of Species by Means of Natural Selection, or the Preservation of Favoured Races in the Struggle for Life. John Murray, London.

Darlington, P.J. 1957. Zoogeography: the Geographical Distributionof Animals. Wiley, New York.

Espeland, M., Murienne, J., 2011. Diversity dynamics in NewCaledonia: towards the end of the museum model? BMC Evol.Biol. 11, 254.

Faivre, J.P., Poirier, J., Routhier, P. 1955. Geographie de laNouvelle-Caledonie. Nouvelles Editions Latines, Paris.

Genise, J.F., Garrouste, R., Nel, P., Grandcolas, P., Maurizot, P.,Cluzel, D., Cornette, R., Fabre, A.-C., Nel, A., 2012.Asthenopodichniumin fossil wood: different trace makers as indicators of different terrestrial palaeoenvironments.Palaeogeogr.

Palaeoclimat. Palaeoecol., 365-366, 184-191.

Gibbs, G.W. 2006. Ghosts of Gondwana: The History of Life inNew Zealand. Craig Potton Publishing, Nelson, New Zealand.

Gillespie, R.G., Roderick, G.K., 2002. Arthropods on islands:colonization, speciation, and conservation. Annu. Rev. Entomol.47, 595-632.

Grandcolas, P. (Ed.), 2008. Zoologia Neocaledonica 6. Biodiversitystudies in New Caledonia. Mem. Mus. Nat. Hist. Nat. 197, 1-326.Grandcolas, P. (Ed.), 2009. Zoologia Neocaledonica 7. Biodiversitystudies in New Caledonia. Mem. Mus. Nat. Hist. Nat., 198, 1-440.

Grandcolas, P., Trewick, S.A., 2016. What is the meaning ofextreme phylogenetic diversity? The case of phylogenetic relictspecies. In: Pellens, R., Grandcolas, P. (Eds.), BiodiversityConservation and Phylogenetic Systematics: Preserving Our Evolutionary Heritage in an Extinction crisis. Springer Open, pp.99-115. 
Grandcolas, P., Murienne, J., Robillard, T., Desutter-Grandcolas,L., Jourdan, H., Guilbert, E., Deharveng, L., 2008. New Caledonia: a very old Darwinian island? Philos. Trans. R. Soc. Lond. B 363, 3309-3317.

Grandcolas, P., Nattier, R., Trewick, S.A., 2014. Relict species: arelict concept? Trends Ecol. Evol. 29, 655-663.

Gressitt, J., 1956. Distribution patterns of Pacific island faunae. Syst. Zool. 5, 11-47. Gregory, J.W., 1930. The geological history of the Pacific Ocean. Nature 125, 750-751.

Guilbert, E., Robillard, T., Jourdan, H., Grandcolas, P. (Eds.),2014. Zoologia Neocaledonica 8. Biodiversity studies in New Caledonia. Mém. Mus. Nat. Hist. Nat., 206, 1-315.

He, T., Lamont, B.B., Fogliani, B., 2016. Pre-Gondwanan-breakup origin of Beauprea (Proteaceae) explains its historical presence inNew Caledonia and New Zealand. Sci Adv. 2, e1501648.

Heads, M., 2008a. Panbiogeography of New Caledonia, south-west Pacific: basal angiosperms on basement terranes, ultramaficendemics inherited from volcanic island arcs and old taxaendemic to young islands. J. Biogeogr. 35, 2153-2175.

Heads, M., 2008b. Biological disjunction along the West Caledonianfault, New Caledonia: a synthesis of molecular phylogenetics andpanbiogeography. Bot. J. Linn. Soc. 158, 470-488.

Heads, M., 2010. Biogeographical affinities of the New Caledonianbiota: a puzzle with 24 pieces. J. Biogeogr. 37, 1179-1201.

Heads, M., 2012. Bayesian transmogrification of clade divergencedates: a critique. J. Biogeogr. 39, 1749-1756.

Holloway, J.D. 1979. A Survey of the Lepidoptera, Biogeographyand Ecology of New Caledonia. Series Entomologica 15. Dr W.Junk, The Hague, Netherlands.

Jeannel, R. 1942. La genèse des faunes terrestres: éléments de biogéographie. Presses Universitaires de France, Paris.

Jordan, G.J., Harrison, P.A., Worth, J.R.P., Williamson, G.J., Kirkpatrick, J.B., 2015. Palaeoendemic plants provide evidencefor persistence of open, well-watered vegetation since theCretaceous. Glob. Ecol. Biogeogr. 25, 127-140.

Ladiges, P.Y., Cantrill, D., 2007. New Caledonia-Australianconnections: biogeographic patterns and geology. Aust. Syst.Bot. 20, 383-389.

Lillie, A.R., Brothers, R.N., 1970. The geology of New Caledonia.New Zealand J. Geol. Geophys. 13, 145-183.

Lowry, P.P. 1998. Diversity, endemism, and extinction in the floraof New Caledonia: a review. In: Peng, C.I., Lowry, P.P. (Eds.),Proceedings of the International Symposium on Rare,Threatened, and Endangered Floras of Asia and the Pacific.Monogr. Ser. No. 16, Institute of Botany, Academica Sinica,Taipei, Taiwan, pp. 181-206.

Luyendyk, B.P., 1995. Hypothesis for Cretaceous rifting of EastGondwana caused by subducted slab capture. Geology, 23, 373-376.

MacArthur, R.H., Wilson, E.O. 1967. The Theory of IslandBiogeography. Princeton University Press, Princeton.

Maurizot, P., Vendé-Leclerc, M. 2009. New Caledonia geologicalmap, scale 1:500 000. Explanatory note by Maurizot P. and Collot J., 2009. Direction de l'Industrie, des Mines et de l'Energie de Nouvelle-Calédonie - Service de la Geologie de NouvelleCalédonie, Bureau de Recherches Géologiques et Minières, Nouméa. [https://dimenc.gouv.nc/sites/default/files/download/13036078.pdf]

Melville, R., 1966. Continental drift, Mesozoic continents and themigrations of the angiosperms. Nature 211, 116-120. 
Morat, P., Veillon, J.M., MacKee, H.S. 1984. FloristicRelationships of New Caledonian Rain Forest Phanerogams. Spec. Pub. no 72, Biogeography of the tropical Pacific Association of Systematics Collections and Bernice P. Bishop Museum, Honolulu, pp. 71-128.

Morat, P., Veillon, J.-M., MacKee, H.S., 1986. Floristic relationships of New Caledonian rainforest phanerogams. Telopea 2, 631-679.

Mortimer, N., 2004. New Zealand's geological foundations.Gondwana Res. 7, 261-272.

Murienne, J., 2009. Testing biodiversity hypotheses in NewCaledonia using phylogenetics. J. Biogeogr. 36, 1433-1434.

Murienne, J., 2010. Panbiogeography of New Caledonia: a responseto Heads (2008). J. Biogeogr. 37, 1626.

Murienne, J., Grandcolas, P., Piulachs, M.D., Belles, X., D’Haese,C., Legendre, F., Pellens, R., Guilbert, E., 2005. Evolution on ashaky piece of Gondwana: is local endemism recent in New Caledonia ? Cladistics 21, 2-7.

Najt, J., Grandcolas, P. (Eds.), 2002. Zoologia Neocaledonica 5.Systématique et endémisme en Nouvelle-Calédonie. Mém. Mus.Nat. Hist. Nat., 187, 1-283.

Najt, J., Matile, L., Eds., 1997. Zoologia Neocaledonica 4.Mémoires du Museum national d'Histoire naturelle, 171, 1-399.

Nattier, R., Robillard, T., Desutter-Grandcolas, L., Couloux, A.,Grandcolas, P., 2011. Older than New Caledonia emergence? Amolecular phylogenetic study of the eneopterine crickets(Orthoptera: Grylloidea) J. Biogeogr. 38, 2195-2209.

Nattier, R., Grandcolas, P., Elias, M., Desutter-Grandcolas, L.,Jourdan, H., Couloux, A., Robillard, T., 2012. Secondary sympatry caused by range expansion informs on the dynamics ofmicroendemism in a biodiversity hotspot. PLoS One 7, e48047.

Nattier, R., Grandcolas, P., Pellens, R., Jourdan, H., Couloux, A.,Poulain, S., Robillard, T., 2013. Climate and soil type together explain the distribution of microendemic species in a biodiversity hotspot. PLoS One 8, e80811.

Nelson, G., Platnick, N. 1981. Systematics and Biogeography: Cladistics and Vicariance. Columbia University Press, New York.

Nunn, P.D. 2009. Vanished Islands and Hidden Continents of the Pacific. University of Hawai'i Press, Honolulu.

Nur, A., Benavraham, Z., 1977. Lost Pacifica continent. Nature 270,41-43.

O'Hara, R.J., 1992. Telling the tree: narrative representation and thestudy of evolutionary history. Biol. Philos. 7, 135-160.

Paris, J.P., 1981. Géologie de la Nouvelle-Calédonie. Un essai de synthèse (Mémoire pour servir de notice explicative à la carte géologique de la Nouvelle-Calédonie à l'échelle du 1/200000). Mém. Bureau Rech. Géol. Min. 113,1-278.

Parsons, P.A., 2005. Environments and evolution: interactionsbetween stress, resource inadequacy and energetic efficiency. Biol.Rev. 80, 589-610.

Pellens, R., Arhends, A., Hollingsworth, P., Grandcolas, P. 2016.Assessing hotspots of evolutionary history with data frommultiple phylogenies: an analysis of endemic clades from NewCaledonia. In: Pellens, R., Grandcolas, P. (Eds.), Biodiversity Conservation and Phylogenetic Systematics: Preserving Our Evolutionary Heritage in an Extinction Crisis. Springer Open,Berlin, pp. 237-262.

Pelletier, B. 2007. Geology of the New Caledonia region and itsimplications for the study of the New Caledonian biodiversity. Doc. Sci. Tech. IRD II7, 17-30.

Pillon, Y., 2012. Time and tempo of diversification in the flora ofNew Caledonia. Bot. J. Linn. Soc. 170, 288-298. 
Pintaud, J.C., Jaffré, T., Puig, H., 2001. Chorology of NewCaledonian palms and possible evidence of Pleistocene rain forest refugia. C. R. Acad. Sci. III 324, 453-463.

Poncet, V., Munoz, F., Munzinger, J., Pillon, Y., Gomez, C.,Couderc, M., Tranchant-Dubreuil, C., Hamon, S., De Kochko, A., 2013. Phylogeography and niche modelling of the relict plant Amborella trichopoda (Amborellaceae) reveal multiple Pleistocene refugia in New Caledonia. Mol. Ecol. 22, 6163-6178.

Pouteau, R., Trueba, S., Feild, T.S., Isnard, S., 2015. New Caledonia: a Pleistocene refugium for rain forest lineages of relict angiosperms. J. Biogeogr. 42, 2062-2077.

Proches, S., Ramdhani, S., Perera, S.J., Ali, J.R., Gairola, S., 2015. Global hotspots in the present-day distribution of ancient animaland plant lineages. Scient. Rep. 5, 15457.

Qiu, Y.-L., Lee, J., Bernasconi-Quadroni, F., Soltis, D.E., Soltis, P.S.,Zanis, M., Zimmer, E.A., Chen, Z., Savolainen, V., Chase, M.W.,1999. The earliest angiosperms: evidence from mitochondrial, plastid and nuclear genomes. Nature 402, 404-407.

Raven, P.H., Axelrod, D.I., 1972. Plate tectonics and Australasian paleobiogeography. Science 176, 1379-1386.

Reusch, D.N., 2011. New Caledonian carbon sinks at the onset of Antarctic glaciation. Geology 39, 807-810.

Routhier, P., 1953. Etude géologique du versant occidental de la Nlle-Calédonie entre le col de Boghen et la Pointe d'Arama. Mém. Soc. Géol. Fr. 32, 1-271.

Skipwith, P.L., Bauer, A., Jackman, T.R., Sadlier, R., 2016. Old but not ancient: coalescent species tree of New Caledonian geckos reveals recent post-inundation diversification. J. Biogeogr. 43,1266-1276.

Smith, S.A., Sadlier, R.A., Bauer, A.M., Austin, C.C., Jackman, T.,2007. Molecular phylogeny of the scincid lizards of NewCaledonia and adjacent areas: evidence for a single origin of theendemic skinks of Tasmantis. Mol. Phyl. Evol. 43, 1151-1166.

Stevens, G.R., 1980. Southwest Pacific faunal palaeobiogeography inMesozoic and Cenozoic times: a review. Palaeogeogr.Palaeoclimatol. Palaeoecol. 31, 153-196.

Swenson, U., Backlund, A., McLoughlin, S., Hill, R.S., 2001.Nothofagus biogeography revisited with special emphasis on theenigmatic distribution of subgenus Brassospora in New Caledonia. Cladistics 17, 28-47.

Swenson, U., Nylinder, S., Munzinger, J., 2014. Sapotaceaebiogeography supports New Caledonia being an old Darwinianisland. J. Biogeogr. 41, 797-809.

Trewick, S.A., Paterson, A.M., Campbell, H.J., 2007. Hello NewZealand. J. Biogeogr. 34, 16.

Wallace, A.R. 1881. Island Life. MacMillan and Co., London.Wanntorp, L., Vajda, V., Raine, J.I., 2011. Past diversity ofProteaceae on subantarctic Campbell Island, a remote outpost ofGondwana. Cret. Res. 32, 357-367.

Waters, J.M., Craw, D., 2006. Goodbye Gondwana? New Zealandbiogeography, geology, and the problem of circularity. Syst. Biol.55, 351-356.

Wilson, E.O., 1961. The nature of the taxon cycle in the Melanesianant fauna. Amer. Nat. 95, 169-193.

Worthy, T.H., Mitri, M., Handley, W.D., Lee, M.S.Y., Anderson,A., Sand, C., 2016. Osteology supports a stem-galliform affinity for the Giant extinct flightless bird Sylviornis neocaledoniae (Sylviornithidae, Galloanseres). PLoS One 11, e0150871.

Zimmerman, E.C., 1942. Distribution and origin of some eastern oceanic insects. Am. Nat. 76, 280-307. 